Received 10 April 2020 Accepted 27 April 2020

Link to DOI:

10.25220/WNJ.V04.S1.0002

Journal Website: www.worldnutrijournal.org

\section{Perspective of Soy Formula and Fiber Intake among Non-Cow's Milk Drinker Pediatric Patients: A Survey among Indonesian Health Care Practitioners}

\author{
Ray Wagiu Basrowi ${ }^{1,2}$, Erika Wasito ${ }^{1}$, Tonny Sundjaja ${ }^{1}$ \\ 1. Danone Specialised Nutrition Indonesia, Jakarta \\ 2. Division of Occupational Medicine Magister, Department of Community Medicine, Faculty of \\ Medicine, Universitas Indonesia
}

\begin{abstract}
Indonesia is one of the highest countries for soy-based product consumption, which the usage also started from early age as breastmilk substitute product, although local regulation and guideline stated that soy-based formula recommended for cow's milk protein allergy. However, evidences showed that soy-based formula supplemented with fiber in non-cow's milk drinker could also have health effect to gastrointestinal system. This online survey aimed to explore the perspective of health care practitioners (HCPs) in recommending soy-based formula for non-cow's milk drinker pediatric patients, as well as identify the required additional ingredient or supplementation, specifically on fiber, in soybased formula. Majority of respondents ( $97 \%$ of pediatricians $(p<0.001)),(96 \%$ of nurses $(p=0.003)),(99 \%$ of midwives $(p<0.001))$ recommended soy-based formula as nutritional product toward non-cow's milk drinker patients. On the added ingredients required, 43\% of respondents mentioned that $\mathrm{AA}$ and $\mathrm{DHA}$ and $31 \%$ mentioned that fibre is the ingredient that need to be added to complete the benefits of soy formula. This study concluded that the overall perspective of HCPs showed that soy-based formula is a nutritional product recommended for non-cow's milk pediatric patients. However, fiber is required to be added to achieve the potential benefits of soy-based formula.
\end{abstract}

Keywords soy based formula, fiber, children, pediatric patients

\section{Introduction}

As one of the highest countries for soy-based product consumption in Asia, Indonesian people has

\begin{tabular}{l}
\hline Corresponding author: \\
Ray Wagiu Basrowi, MD, PhD \\
Medical and Scientific Affairs Division - HN \\
Department, Danone SN, Indonesia \\
E-mail address: ray.basrowil@danone.com \\
\hline
\end{tabular}

used this food as nutritional source since early age. This includes the use of soy-based formula as the breastmilk substitute product. ${ }^{1}$

Despite the widely used of soy-based formula, Indonesia Pediatric Association (IDAI) specifically recommend this only for infants with Cow's Milk Protein Allergy (CMPA) as well as for several other related medical indications such as post diarrhea lactose intolerance, galactosemia and primary lactase deficiency. Based on the policy and regulation on Indonesia Food and Drugs Association (BPOM) as well as IDAI Guidelines, the management of CMPA consists of diagnosis and 
treatment in children with CMPA. Specifically, for the treatment, the algorithm suggests to eliminates allergen mainly cow's milk protein. For breastfed infant, the infants were suggested to continue breastfeed exclusively and recommended the mother to avoid the consumption of all cow's milk protein and its derivatives. Soy based infant's formula may be consider for availability and affordability concern. ${ }^{2,3}$

Evidences showed that supplementing dietary fiber in children may improve overall diet quality. ${ }^{4}$ Dietary fiber intake beneficial in term of physiological effects including reducing postprandial glucose concentrations, improving fecal bulk, promoting laxation, interfering with fat and cholesterol absorption, and altering bacteria populations in the gut microbiome..$^{5-7}$ In the gastrointestinal system, soy fiber has been shown to reduce the duration of watery stools during acute diarrhea caused by bacterial and viral pathogens in underdeveloped countries. A study done in middleclass American children showed the efficacy of soy fiber supplemented infant formula, including stool characteristics and weight. ${ }^{8}$

In regards to the fiber content, among plant protein source form legumes, soybeans known as the second lowest fiber source after peanuts $(9.3 \mathrm{~g} / 100 \mathrm{~g}$ versus $8.5 \mathrm{~g} / 100 \mathrm{~g}$, respectively) as compared to the highest content found in green peas $(25.5 \mathrm{~g} / 100 \mathrm{~g}){ }^{9}$ However, soybean dietary fiber have a role in antioxidant scavenging activity in plant tissues and maybe also for human. ${ }^{10}$

On the HCPs recommendation pattern toward nutritional product, studies among pediatrician showed that in order for them to utilize probiotic use correctly, it is important to keep updated about new knowledge through various sources and methods, eq. continuous medical education (CME), lectures, workshops, case-based learning, clinical experiences, preceptorships, and even direct information via interaction with representatives from nutrition companies. ${ }^{11,12} \mathrm{~A}$ review showed that education have little impact and knowledge increase observed with multiple learning methods. ${ }^{13}$

This survey aimed to explore the perspective of health care practitioners (HCPs) in recommending soy-based formula for non-cow's milk drinker pediatric patients, as well as identify the required additional ingredient or supplementation, specifically on fiber, in soy-based formula.

\section{Method}

An online survey was conducted to 350 Health Care Practitioners (HCPs) in January 2020 for the period of three weeks. The survey was hosted on the Google-form survey platform and distributed through email to all respondents. Several reminders were sent via phone call, email, WhatsApp and text messages, once in every week. Respondents taken from Danone HN HCPs internal database and participants who expressed an interest showed in electronic informed consent in the preview of the survey. The questionnaire adapted from the previous cross-sectional study, ${ }^{14}$ and developed in the format of multiple choices, True/False, and Yes/No. At the end of the study, participants were provided with debriefing information and contact details of the research team. A chi-square test was used to analyze cross-tabulated data for bivariate analysis and linear regression model for multivariate analysis, using SPSS version 20, with all outcome variables taken at the $5 \%$ significance level $(\mathrm{p}<0.05)$.

\section{Result}

The survey sent to 350 respondents with 277 respondents responded by the end of the survey, which was resulted to $79 \%$ response rate. Majority of respondents participated in this survey were pediatricians $(n=147)$, followed by nurses $(n=68)$, and midwives $(n=62)$. As shown in Table 1 , most of the pediatricians were consider senior in term of age and length of service, while the average age and length of service of midwives and nurses mostly less than 41 years old and less than 15 years of service, respectively. In term of institution where the respondents work, majority of midwives were affiliated with private hospital and/or private clinics, while the proportions of affiliations among pediatricians and nurses were slightly balanced between private hospital and government hospital. $100 \%$ of the respondents confirmed that they were ever consulted with non-cow's milk drinkers' patients in the last month. 
Table 1. Demographic characteristic of respondents

\begin{tabular}{|c|c|c|c|c|c|c|}
\hline \multirow[t]{2}{*}{ Variables } & \multicolumn{2}{|c|}{$\begin{array}{c}\text { Pediatricians } \\
n=147\end{array}$} & \multicolumn{2}{|c|}{$\begin{array}{l}\text { Nurses } \\
\mathrm{n}=68\end{array}$} & \multicolumn{2}{|c|}{$\begin{array}{c}\text { Midwives } \\
\mathrm{n}=62\end{array}$} \\
\hline & $\mathrm{n}$ & $\%$ & $\mathrm{n}$ & $\%$ & $\mathrm{n}$ & $\%$ \\
\hline \multicolumn{7}{|l|}{ Age } \\
\hline$<41$ & 46 & 33 & 51 & 37 & 41 & 30 \\
\hline$\geq 41$ & 101 & 73 & 17 & 12 & 21 & 15 \\
\hline \multicolumn{7}{|l|}{ Length of Service } \\
\hline$<15$ years & 34 & 23 & 15 & 23 & 12 & 19 \\
\hline$\geq 15$ years & 113 & 77 & 53 & 77 & 50 & 81 \\
\hline \multicolumn{7}{|l|}{ Affiliation } \\
\hline Private hospital & 79 & 54 & 40 & 54 & 50 & 81 \\
\hline Government hospital & 68 & 46 & 28 & 46 & 12 & 19 \\
\hline \multicolumn{7}{|l|}{ Area } \\
\hline West & 116 & 79 & 56 & 79 & 48 & 77 \\
\hline East & 31 & 21 & 12 & 21 & 14 & 23 \\
\hline \multicolumn{7}{|c|}{ Ever Consulted with Non-Cow's Milk } \\
\hline Yes & 147 & 100 & 68 & 100 & 62 & 100 \\
\hline No & 0 & 0 & 0 & 0 & 0 & 0 \\
\hline
\end{tabular}

Based on respondent' reports during consultation, We further analysed the recommendation level on the reason of why their patients did not drink cow's soy formula based on the HCP's characteristic milk was related to cow's milk protein allergy (59\%) profile. Table 2 shows that $97 \%$ of pediatricians (p and followed by diarrhea (31\%). As shown in Figure $<0.001$ ), 96\% of nurses ( $\mathrm{p}=0.003$ ), and $99 \%$ of 1 , there were few non-specific medical reasons also mentioned, as well as constipation. When the respondents being asked about the nutritional products recommended for patients whose noncow's milk drinker, as shown in Figure 2, soy midwives $(p<0.001)$ mentioned that soy formula is a recommended nutritional product toward non-cow's milk drinker patients, and the result showed statistically significant across HCP's profile.

This survey also explores the perspective of formula was recommended by majority of respondent toward specific ingredients that need to respondents $(61 \%)$.

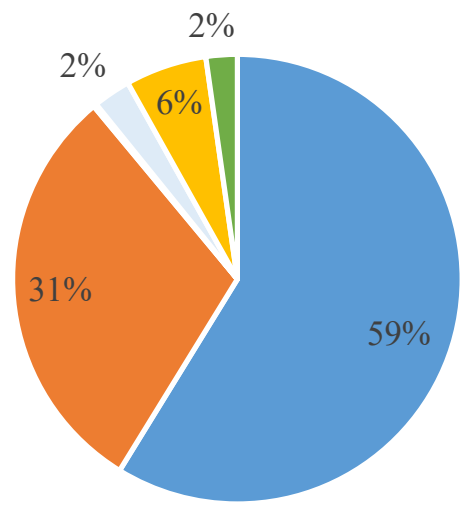

- Cows Milk Protein Allergy

- Diarrhea

Constipation

- No Specific Medical Reason

- Others

Figure 1. Reason to not consume cow's milk reported from patients during consultation 


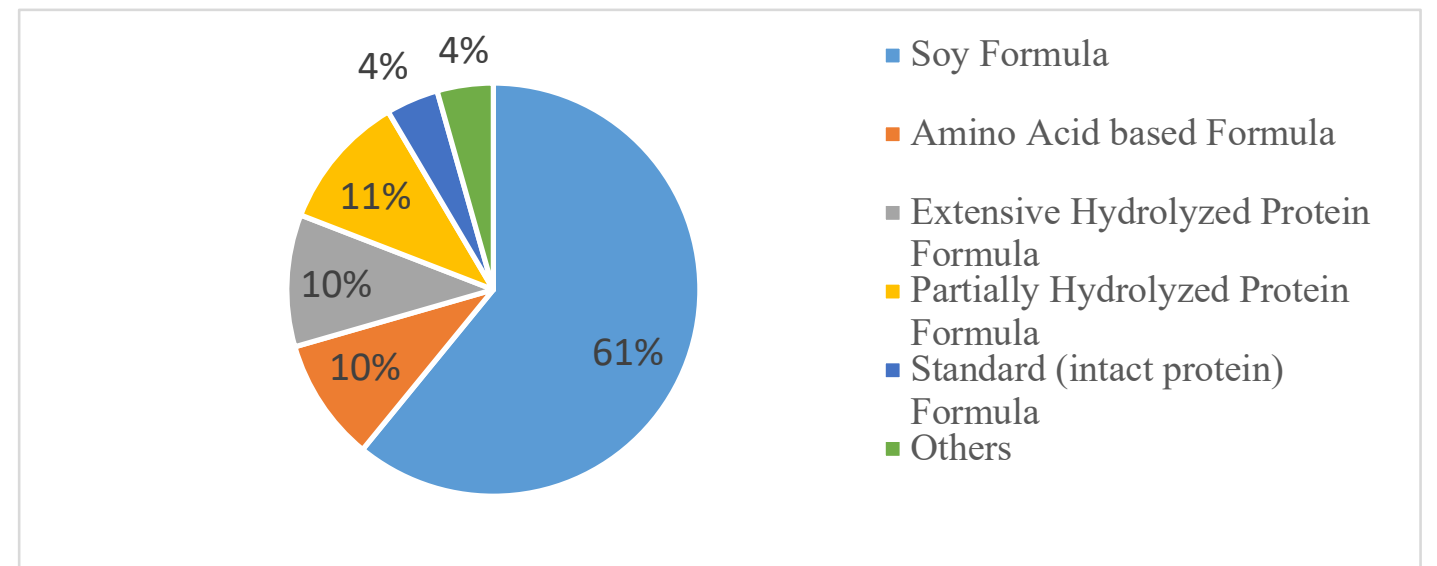

Figure 2. Nutritional products recommended by HCP for non-cow's milk drinkers

Table 2. Cross tabulation of recommendation level of soy formula

\begin{tabular}{|c|c|c|c|c|c|c|c|c|c|}
\hline \multirow[t]{2}{*}{ Variables } & \multicolumn{2}{|c|}{$\begin{array}{c}\text { Pediatricians } \\
\mathrm{n}=147\end{array}$} & \multirow[t]{2}{*}{$\mathrm{p}$} & \multicolumn{2}{|c|}{$\begin{array}{c}\text { Nurses } \\
\mathrm{n}=68\end{array}$} & \multirow[t]{2}{*}{$\mathrm{p}$} & \multicolumn{2}{|c|}{$\begin{array}{c}\text { Midwives } \\
\mathrm{n}=62\end{array}$} & \multirow[t]{2}{*}{$\mathrm{p}$} \\
\hline & $\mathrm{n}$ & $\%$ & & $\mathrm{n}$ & $\%$ & & $\mathrm{n}$ & $\%$ & \\
\hline $\begin{array}{l}\text { Soy is a recommended } \\
\text { product for non-cow's } \\
\text { milk drinker }\end{array}$ & 139 & 95 & $<0,001$ & 65 & 96 & 0,003 & 61 & 99 & $<0,001$ \\
\hline $\begin{array}{l}\text { Soy is not a } \\
\text { recommended product for } \\
\text { non-cow's milk drinker }\end{array}$ & 8 & 5 & & 3 & 4 & & 1 & 1 & \\
\hline
\end{tabular}

be added in the soy formula. Figure 3 showed that $43 \%$ of respondents mentioned that AA and DHA need to be added and $31 \%$ also mentioned that fibre is the ingredient that need to be added to complete the benefits of soy formula. The respondents were also further asked their perspective toward adequacy level of fibre among non-cow's milk drinker patients, and as shown in Table $3,31 \%$ of pediatricians mentioned that the fibre intake among non-cow's milk drinker patients were inadequate to very inadequate, similar with the perspective of nurses $(22 \%)$ and midwives (24\%), although the result was not statistically significant.

Even though the multivariate analysis in Table 4 showed no statistically significant among demographic characteristic of respondents, however among the midwives and nurses the result showed majority of the respondents $(79 \%$ of midwives and $56 \%$ of nurses) who work in private hospital/clinics recommending soy formula for non-cow's milk drinker compare to those who work in government hospital, and the number showed clinically important.

\section{Discussion}

This survey reported that the overall perspective of health care practitioners (HCPs) was in favor with soy formula recommendation to non-cow's milk drinker pediatric patients. This finding is consistent with previous studies and recommendations available in Indonesia as well as global recommendations. ${ }^{2,15,16}$ Studies mentioned that the recommendation of soy-based formula in non-cow's milk drinker pediatric patients is higher than regular or standard formula. It is also because the local pediatric association regulates the use of soy formula under certain medical conditions, ${ }^{2}$ mainly for cow's milk protein allergy (CMPA) diagnosed patient. Knowing that the symptoms and complaints of CMPA patients could also differ, including gastro intestinal symptoms such as diarrhea and constipation, the findings from this survey that showing the reasons of patients consuming soy formula when they consulted to HCPs also validated. ${ }^{17}$ The other study also stated that the most 


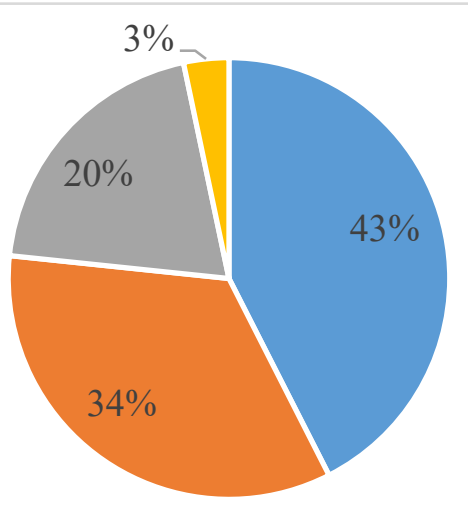

- AA \& DHA

- Fiber

- Amino Acid

- Others (Taste, Prebiotic,

Probiotic, Synbiotic, Vitamin, Mineral, Fat, Calories)

Figure 3. Perspective on specific ingredients that should be added in soy milk

Table 3. Perspective on fibre adequacy in children who couldn't drink cow's milk among healthcare professionals and its relationship

\begin{tabular}{lccccccccc}
\hline \multicolumn{1}{c}{ Variables } & \multicolumn{2}{c}{$\begin{array}{c}\text { Pediatricians } \\
\mathrm{n}=147\end{array}$} & $\mathrm{p}$ & \multicolumn{2}{c}{$\begin{array}{c}\text { Nurses } \\
\mathrm{n}=68\end{array}$} & $\mathrm{p}$ & \multicolumn{2}{c}{ Midwives } & $\mathrm{p}$ \\
\cline { 2 - 9 } & $\mathrm{n}$ & $\%$ & & $\mathrm{n}$ & $\%$ & & $\mathrm{n}$ & $\%$ & \\
\hline Very inadequate & 3 & 2 & 0.46 & 2 & 3 & 0.68 & 1 & 2 & 0.61 \\
Inadequate & 42 & 29 & & 13 & 19 & & 14 & 22 & \\
Adequate & 102 & 69 & & 53 & 77 & & 47 & 76 & \\
\hline
\end{tabular}

Table 4. Multivariate analysis of HCP's recommendation level toward soy formula for non-cow's milk drinker based on demographic characteristic

\begin{tabular}{|c|c|c|c|c|c|c|c|c|c|c|c|c|c|c|c|}
\hline \multirow{3}{*}{ Variables } & \multicolumn{4}{|c|}{$\begin{array}{l}\text { Pediatricians } \\
\mathrm{n}=147\end{array}$} & \multirow[t]{3}{*}{$\mathrm{p}$} & \multicolumn{4}{|c|}{$\begin{array}{c}\text { Nurses } \\
\mathrm{n}=68\end{array}$} & \multirow[t]{3}{*}{$\mathrm{p}$} & \multicolumn{4}{|c|}{$\begin{array}{l}\text { Midwifes } \\
\mathrm{n}=62\end{array}$} & \multirow[t]{3}{*}{$\mathrm{P}$} \\
\hline & \multicolumn{2}{|c|}{ Recommend } & \multicolumn{2}{|c|}{$\begin{array}{c}\text { Do Not } \\
\text { Recommend }\end{array}$} & & \multicolumn{2}{|c|}{ Recommend } & \multicolumn{2}{|c|}{$\begin{array}{c}\text { Do Not } \\
\text { Recommended }\end{array}$} & & \multicolumn{2}{|c|}{ Recommend } & \multicolumn{2}{|c|}{$\begin{array}{c}\text { Do Not } \\
\text { Recommend }\end{array}$} & \\
\hline & $\mathrm{n}$ & $\%$ & $\mathrm{n}$ & $\%$ & & $\mathrm{n}$ & $\%$ & $\mathrm{n}$ & $\%$ & & $\mathrm{n}$ & $\%$ & $\mathrm{n}$ & $\%$ & \\
\hline Age & & & & & 1.00 & & & & & 0.56 & & & & & \\
\hline$<41$ & 44 & 30 & 2 & 1 & & 48 & 71 & 3 & 4 & & 40 & 65 & 1 & 1 & 1.00 \\
\hline$\geq 41$ & 95 & 65 & 6 & 4 & & 17 & 25 & 0 & 0 & & 21 & 34 & 0 & 0 & \\
\hline $\begin{array}{l}\text { Length of } \\
\text { Service }\end{array}$ & & & & & 0.71 & & & & & 1.00 & & & & & 1.00 \\
\hline$<15$ years & 97 & 66 & 5 & 3 & & 44 & 65 & 0 & 0 & & 45 & 74 & 1 & 1 & \\
\hline$\geq 15$ years & 42 & 29 & 3 & 2 & & 21 & 31 & 3 & 4 & & 16 & 25 & 0 & 0 & \\
\hline Affiliation & & & & & 0.72 & & & & & 0.54 & & & & & 1.00 \\
\hline Private & 74 & 50 & 5 & 3 & & 38 & 56 & 1 & 1 & & 49 & 79 & 1 & 1 & \\
\hline Government & 65 & 45 & 3 & 2 & & 27 & 40 & 2 & 3 & & 12 & 20 & 0 & 0 & \\
\hline Area & & & & & 0.67 & & & & & 0.23 & & & & & 1.00 \\
\hline West & 110 & 75 & 6 & 4 & & 53 & 78 & 0 & 0 & & 48 & 77 & 0 & 0 & \\
\hline East & 29 & 20 & 2 & 1 & & 12 & 18 & 3 & 4 & & 13 & 22 & 1 & 1 & \\
\hline
\end{tabular}

common reason of recommending soy-based formula by HCPs is to relief of perceived formula intolerance (spitting, vomiting, fussiness) or symptoms of colic since this can be a symptom of
CMPA. Other findings of this study also showed that partial hydrolysed formula is not the first choice of HCPs for non-cow's milk drinker patients. This might be positively correlates with the previous 
studies and review mentioned that partially hydrolysed formula is more recommended for prevention of CMPA and the benefits of partial hydrolysed formula to gastrointestinal manifestations will be more positive when added with prebiotic, probiotic, palmitic acid, including human milk oligosaccharide. ${ }^{18}$

The recommendation level of soy-based formula across HCPs reported from this study also showed interesting facts. Despite the result showed statistically not significant, however there is higher percentage of HCPs working in government hospitals recommending soy-based formula compare to their colleagues who works in private hospital or clinics. Study in China showed that there is a situation where doctors working in county hospital have more supportive attitude to national essential medicine policy, as they were more accessible to education, training on rational drug use, and better acquisition of medicine knowledge. ${ }^{19}$ The assumption of this hypothesis also applied to finding of this study, since the local regulation and recommendation of soy-based formula were established here in Indonesia. Previous study on prescription pattern in Indonesia also confirms this finding. ${ }^{14}$ Similar findings have also been seen in the variable of length of service across HCPs. This study showed that despite the statistically not significant result, the HCPs with length of service less than 15 years were more open to recommending soy-based formula.

Other findings from this study is the perspective of HCPs toward fiber intake and ingredient-wise perspective in soy-based formula. Apart of AA and DHA, high number of respondents mentioned that fiber should be added into the soybased formula to achieve ultimate benefits. Even though majority of respondents also mentioned that fiber intake among non-cow's milk drinker children is adequate, but more than $30 \%$ of pediatricians and more than $20 \%$ of nurses and midwives still acknowledging that there is still a potential inadequacy of fiber intake among their non-cow's milk drinker patient. Study showed that fiber content of soybeans as the source isolated soy-based formula consider low, even second lowest after peanuts. ${ }^{9}$ Study suggested that fiber supplementation especially in the form of oligosaccharide (FOS) and inulin demonstrated positive tolerance in children, ${ }^{20}$ and also showed beneficial effect in gastrointestinal health. ${ }^{21,22}$ The use of fiber-supplemented soy formula may reduce the duration of diarrheal symptoms in U. S. infants more than 6 months of age with acute diarrhea. ${ }^{8}$ Therefore the perspective of respondents of this study toward additional fiber as potential ingredient in soy-based formula is evidence based and consistent with studies and review available.

This survey has major limitation as it is designed as an online survey whereas the subjectivity of respondents potentially interferes the objective of the reports as well as the challenges to identify the factors influencing respondents to recommends the nutritional products.

\section{Conclusion}

Overall perspective of HCPs showed that soy-based formula is a nutritional product recommended for non-cow's milk pediatric patients. However, fiber is required to be added to achieve the potential benefits of soy-based formula.

\section{Conflict of Interest}

This survey is funded by Danone SN Indonesia.

\section{Open Access}

This article is distributed under the terms of the Creative Commons Attribution 4.0 International Licence

(http://creativecommons.org/licenses/by/4.0/), which permits unrestricted use, distribution, and reproduction in any medium, provided you give appropriate credit to the original author(s) and the source, provide a link to the Creative Commons license, and indicate if changes were made.

\section{Reference}

1. Hill LW, Stuart HC. A soy bean food preparation for feeding infants with milk idiosyncrasy. J. Am. Med. Assoc 1929;93:985. [Google Scholar]

2. Ikatan Dokter Indonesia (IDAI). Rekomendasi Diagnosis dan Tatalaksana Alergi Susu Sapi. Badan Penerbit Ikatan Dokter Anak Indonesia (2014): Jakarta 
3. BPOM RI. Peraturan Badan Pengawas Obat dan Makanan Nomor 1/2008 tentang Pengawasan Pangan Olahan untuk keperluan gizi khusus. BPOM Republik Indonesia. 2008

4. Finn K, Jacquier E, Kineman B, Storm H, Carvalho R. Nutrient intakes and sources of fiber among children with low and high dietary fiber intake: the 2016 feeding infants and toddlers study (FITS), a cross-sectional survey. BMC Pediatr 2019;19(1):446. doi: 10.1186/s12887-019-1822-y. [Google Scholar]

5. Chen HL, Haack VS, Janecky CW, Vollendorf NW, Marlett JA. Mechanisms by which wheat bran and oat bran increase stool weight in humans. Am J Clin Nutr 1998;68(3):711. doi: 10.1093/ajen/68.3.711. [Google Scholar]

6. Yu K, Ke MY, Li WH, Zhang SQ, Fang XC. The impact of soluble dietary fibre on gastric emptying, postprandial blood glucose and insulin in patients with type 2 diabetes. Asia Pac J Clin Nutr 2014;23(2):210. [Google Scholar]

7. Wu K, Bowman R, Welch AA, Luben RN, Wareham $\mathrm{N}$, Khaw KT, et al. Apolipoprotein E polymorphisms, dietary fat and fibre, and serum lipids: the EPIC Norfolk study. Eur Heart J 2007;28(23):2930. doi: 10.1093/eurheartj/ehm482. [Google Scholar]

8. Vanderhoof J, Murray ND, Paule CL, Ostrom KM. Use of soy fiber in acute diarrhea in infants and toddlers. Clinical pediatrics 1997;36(3):135-9. [Google Scholar]

9. Rizzo G, Baroni L. Soy, soy foods and their role in vegetarian diets. Nutrients 2018;10(1):43. [Google Scholar]

10. O'Keefe S, Bianchi L, Sharman J. Soybean Nutrition. Nutr Metab (Lond 2015;1(2):1006. [Google Scholar]

11. Al-Azri H, Ratnapalan S. Problem-based learning in continuing medical education: review of randomized controlled trials. Canadian family physician 2014 Feb;60(2):157-65. [Google Scholar]

12. Marinopoulos SS, Baumann MH. Effectiveness of Continuing Medical Education: American College of Chest Physicians Evidence-Based Educational Guidelines. CHEST 2009;135:17. [Google Scholar]

13. Ahmed K, Wang TT, Ashrafian H, Layer GT, Darzi A, Athanasiou T. The Effectiveness of Continuing Medical Education for Specialist Resertification. Can Urol Assoc J 2013;7(7-8):266. [Google Scholar]

14. Basrowi RW, Krisnamurti D, Wibowo Y, Vandenplas Y (2019) Factors influencing probiotics recommendation among pediatricians in Indonesia.
2019;6:1-4. doi: 10.15761/IFNM.1000265. [Google Scholar]

15. Reynaldo A, Hegar B. Soy Infant and Extensively Hydrolyzed Formula as Therapeutic Formula for Cow's Milk Protein Allergy. The Indonesian Journal of Gastroenterology Hepatology and Digestive Endoscopy 2014;15(2):98-104. [Google Scholar]

16. World Health Organization (WHO). Standard for Infant Formula and Formulas for Special Medical Purposes Intended for Infants. CODEX STAN 721981 Rev 2017

17. Vandenplas Y, Greef, E. De, Devreker T, Hauser B. Soy Infant Formula: is it that bad. Acta Paediatrica 2011;100:162-66. [Google Scholar]

18. Vandenplas Y, Munasir Z, Hegar B, Kumarawati D, Suryawan A, Kadim M, Djais JT, Basrowi RW, Krisnamurti D. A perspective on partially hydrolyzed protein infant formula in nonexclusively breastfed infants. Korean journal of pediatrics 2019;62(5):14954. [Google Scholar]

19. Lasekan J, Baggs G, Acosta S, et al. Soy ProteinBased Infant Formulas with Supplemental Fructooligosaccharides: Gastrointestinal Tolerance and Hydration Status in Newborn Infants. Nutrients 2015;7:3022-37. doi: 10.3390/nu7043022. [Google Scholar]

20. Orel R, ReberŠak L. Clinical Effects of Prebiotics in Pediatric Population. Indian Pediatr 2016;53:108393. [Google Scholar]

21. Hegar B, Wibowo Y, Basrowi RW, Ranuh RG, Sudarmo SM, Munasir Z, et al. The Role of Two Human Milk Oligosaccharides, 2'-Fucosyllactose and Lacto-N-Neotetraose, in Infant Nutrition. Pediatr Gastroenterol Hepatol Nutr 2019;22(4):330-40. doi: 10.5223/pghn.2019.22.4.330. [Google Scholar] 